\title{
Relationship between phosphate affinities and cell size and shape in various bacteria and phytoplankton
}

\author{
Hanita Tambi, Gro Anita Fonnes Flaten, Jorun K. Egge, Gunhild Bødtker, \\ Anita Jacobsen, T. Frede Thingstad ${ }^{*}$
}

Department of Biology, University of Bergen, PO Box 7800, 5020 Bergen, Norway

\begin{abstract}
Substrate affinity expresses the ability of an osmotroph organism to compete for a substrate at permanently low external concentrations and is thus a central parameter in conceptual and mathematical models of aquatic food webs. Assuming diffusion transport in the surrounding medium to be the limiting process at low external substrate concentrations, the theoretical maximum affinity $\left(\alpha^{\max }\right)$ and its dependence on cell size and shape for a given osmotroph organism can be calculated from Fick's law of diffusion in combination with knowledge of the amount of substrate required to form a new cell. For a non-respired substrate, the actual affinity $(\alpha)$ can also be expressed as the biomass-specific turnover rate of the substrate, $\alpha=(T B)^{-1}$. Combining a measure of biomass $(B)$, with determination of substrate turnover time $(T)$, the affinity can thus be determined experimentally. We used this approach to compare measured with theoretical maximum affinities for phosphate in laboratory cultures of osmotrophic microorganisms. For bacteria and autotrophic flagellates, we found relatively good agreement between experimental and theoretical maximum values, suggesting that diffusion limitation is actually approached in P-limited cultures. Assuming P-free vacuoles, the theory predicts diatom affinities to exceed that of similarly sized flagellates. This prediction is consistent with our experimental observations. Previous reports of diatoms being unsuccessful under P-limited conditions may therefore need a more complex explanation than lack of competitive ability in diatoms.
\end{abstract}

KEY WORDS: Affinity $\cdot$ Phosphate $\cdot$ Bacteria $\cdot$ Phytoplankton · Osmotrophs $\cdot$ Nutrient competition

Resale or republication not permitted without written consent of the publisher

\section{INTRODUCTION}

For many years $\mathrm{N}$ was considered the main limiting nutrient in marine systems (1999). Over the last 3 decades, this view has been challenged (1) by experiments in high nutrient, low chlorophyll (HNLC) regions giving clear indications of Fe-limitation (Boyd 2002) and (2) by an increasing amount of evidence for P-limitation in marine areas such as the Mediterranean (Thingstad et al. 1998, Zohary \& Robarts 1998), the Sargasso Sea (Wu et al. 2000), parts of the Atlantic (Ammerman et al. 2003, Vidal et al. 2003) and in subtropical Pacific waters (Björkman et al. 2000, Karl et al. 2001).

In environments where phosphorus is the nutrient that limits growth rate, the relative competitive ability for phosphate by osmotrophic organisms supposedly has a key role, influencing the pathway through which phosphate enters and is transported through the microbial part of the pelagic food web to higher trophic levels. This channelling of phosphate through the microbial food web is believed to be influenced by many processes and parameters including the phosphate storage ability of cells (e.g. Isvánovics et al. 2000), and loss processes such as leakage of phosphate (e.g. Vadstein 1998), predation (e.g. Gasol et al. 2002) and viral lysis (e.g. Wilhelm \& Suttle 1999).

Here we focus solely on the ability of osmotrophs to compete at permanently low substrate concentrations. Crucial for this is the initial slope of the substrate versus specific uptake rate relationship, here defined as their maximum specific affinity $\left(\alpha^{\max }\right)$. The unit for this 
affinity is volume of water cleared for substrate per unit biomass per unit time, and thus corresponds conceptually to the maximum clearance rate of a phagotrophic organism. Affinities and clearance rates thus constitute a common subset of parameters whose absolute and relative values are crucial in determining both steady state (Thingstad 2000) and transient behaviour (Thingstad et al. 2007) in mathematical models for the microbial ecosystem. Theoretical values for $\alpha^{\max }$ can be calculated based on the assumption that, at sufficiently low substrate concentrations, transport by molecular diffusion to the cell surface becomes the rate-limiting step. The assumption is thus that maximum affinity is reached when the diffusive transport is so low that all molecules hitting the cell surface are captured by the organism (Kiørboe 2008). The expression for $\alpha^{\max }$ will depend on cell size and shape and on minimum cell quota for $\mathrm{P}$. The minimum cell quota will depend both on factors such as elemental C:P ratio in the cytoplasm and on morphological features such as a vacuole that can be empty of P. We derived expressions for flagellates, coccoid and rod-shaped bacteria and spherical and rod-shaped diatoms for comparison with experimental results (see Table 1).

Uptake as a function of substrate concentration is often described by a Michaelis-Menten saturation curve. When substrate concentration is sufficiently low, the initial part of the curve can be approximated by a linear relationship, where total uptake $V$ from a population with biomass $B$ is proportional to substrate concentration $S: V=\alpha^{\max } S B$. Since turnover time $T$ for phosphate is defined as $T=S V^{-1}$, it follows that $\alpha^{\max }=$ $(T B)^{-1}$. Specific affinity can thus also be interpreted as the biomass-specific turnover rate: turnover rate $=T^{-1}$. Whereas $S$ cannot be easily measured under P-limited conditions (Hudson et al. 2000), $T$ and $B$ can, allowing a technically easy determination of specific affinity $\alpha$ as suggested by Thingstad \& Rassoulzadegan (1999).

Despite the importance ascribed to cell size in most microbial food web models, relatively little experimental support for the theoretically expected size-dependence of affinity seems to be available. Here, we collected experimental estimates of $\alpha$ for osmotrophic microorganisms belonging to different groups and covering a wide range in size. Using these as minimum estimates for $\alpha^{\max }$, we are able to compare experimental values (see Table 2) to the theoretical relationships based on diffusion limitation (see Table 1).

\section{MATERIALS AND METHODS}

Organisms. Organisms from different groups of osmotrophs (organisms using dissolved substrates) were chosen.
Bacteria: Two bacterial strains (Roseobacter algicola and Vibrio splendidus) were originally isolated from the bay of Villefrance-sur-Mer in the Mediterranean Sea $\left(43^{\circ} 41^{\prime} N, 7^{\circ} 19^{\prime} E\right)$ and off Scripps Pier in the Southern California Bight $\left(32^{\circ} 53^{\prime} \mathrm{N}, 117^{\circ} 15^{\prime} \mathrm{W}\right)$, respectively (Hagström et al. 2000).

Autotrophic flagellates: Cultures of the flagellates Isochrysis sp., Pavlova lutheri (Droop) Green 1975 and Tetraselmis suecica (Kylin) Butcher, 1959 were used. The $P$. lutheri culture was made axenic by antibiotic treatment, and the culture was tested for sterility at each transfer (Droop 1967).

Dinoflagellates: The dinoflagellate Heterocapsa triquetra (Ehrenberg) Stein 1883 was isolated from Øresund, Denmark (Schmidt \& Hansen 2001). The culture was provided by the culture collection of the Marine Biological Laboratory, Helsingør, Denmark.

Diatoms: Chaetoceros muelleri, Lemmermann 1898, was obtained from the Culture Collection of Protozoa and Algae (CCAP). Skeletonema marinoi Sarno \& Zingone, Chaetoceros curvisetus Cleve, Thalassiosira weissflogii (Grunow) G. Fryxell \& Hasle, Nitzschia longissima (Brébisson, in Kützing) Ralfs in Pritchard and Thalassionema nitzschioides (Grunow) Mereschkowsky were obtained from the Algae Laboratory, Department of Biology, University of Bergen. The species were isolated from Raunefjorden close to Bergen by Dale Evensen (pers. comm.). The diatom Skeletonema marinoi from this area has, in earlier investigations from this area, been recorded as Skeletonema costatum.

Derivation of expressions. We derived expressions for flagellates, coccoid and rod-shaped bacteria and spherical and rod-shaped diatoms for comparison with experimental results (Table 1). The diffusive flux $J$ to a sphere of radius $r$ is $J=4 \pi \operatorname{Dr}\left(S_{\infty}-S_{r}\right)$ (Jumars et al. 1993), where $D$ is the diffusion rate for phosphate in seawater and $S_{\infty}$ and $S_{r}$ the phosphate concentrations at infinite distance and at the cell wall, respectively. The maximum flux when the cell captures molecules as fast as they are transported is thus $J^{\max }=4 \pi D r S_{\infty}$. Dividing $J^{\max }$ by the minimum phosphorus cell quota $Q^{\text {min }}$ gives the maximum growth rate obtainable for a given $S_{\infty}: \mu=\left(4 \pi D r / Q^{\min }\right) S_{\infty}$. From this, $\alpha^{\max }=$ $4 \pi D r / Q^{\min }$. Replacing $Q^{\min }$ with the expression $Q^{\min }=$ $(4 / 3) \pi r^{3} \sigma$, where $\sigma$ is the average cell concentration of $\mathrm{P}$, gives $\alpha^{\max }=3 D / \sigma r^{-2}$.

Assuming the biomass to contain $22 \%$ dry weight, $50 \%$ of which is carbon, a specific weight of $1.1 \mathrm{~g} \mathrm{~cm}^{-3}$ (Bratbak \& Dundas 1984) and a Redfield molar C:P ratio of 106, a 'standard' $\sigma=9.510^{-8} \mathrm{nmol} \mathrm{P} \mu \mathrm{m}^{-3}$ is obtained. For bacteria we used a molar C:P ratio of 50, increasing $\sigma$ by a factor of 50/106.

For diatoms we assumed a cytoplasm layer of thickness $d=1 \mu \mathrm{m}$ and the vacuole to be P-free. To 
Table 1. Derivation of the relationships between cell size, cell shape and maximum specific affinity $\left(\alpha^{\max }\right)$ for different cell types used to draw the theoretical curves in Fig. 1. D: diffusion rate for phosphate in seawater; $\sigma$ : average cell conc. of $P$; $r$ : sphere radius; $d$ : thickness of cytoplasm; $g$ : length $/ r$. See 'Materials and methods' for details

\begin{tabular}{|lcc|}
\hline Cell type & $\begin{array}{c}\text { Analytical } \\
\text { expression }\end{array}$ & $\begin{array}{c}\text { Equivalent } \\
\text { spherical radius }\end{array}$ \\
\hline Spheres & $\frac{3 D}{\sigma r^{2}}$ for $\alpha^{\max }$ & $r$ \\
Rods with $0<g \leq 16$ & $\frac{3 D r}{\sigma\left(r^{3}-(r-d)^{3}\right)}$ & $r$ \\
Rod-shaped diatoms & $\frac{\left(8+4.10 g^{0.76}\right) D}{\sigma \pi r^{2} g}$ & $r \sqrt[3]{\frac{3}{4} g}$ \\
& $\frac{\left(8+4.10 g^{0.76}\right) r}{\sigma \pi\left(r^{3} g-(r-d)^{2}(r g-2 d)\right)}$ & $r \sqrt[3]{\frac{3}{4} g}$ \\
\hline
\end{tabular}

Particulate phosphorus. Bacterial samples were filtered in triplicate through $47 \mathrm{~mm}$ polycarbonate filters of $0.2 \mu \mathrm{m}$ pore size. The axenic Pavlova lutheri cultures were filtered in triplicate through $47 \mathrm{~mm}$ polycarbonate filters of $1.0 \mu \mathrm{m}$ pore size and the non-axenic cultures through $47 \mathrm{~mm}$ polycarbonate filters of 2.0 (Chaetoceros muelleri, Isochrysis sp. and Tetraselmis suecica) or $5.0 \mu \mathrm{m}$ pore size (diatoms). Filters were transferred to polycarbonate tubes and wet oxidation in acid persulphate was performed according to Koroleff (1983). Filters and reagent blanks were subtracted.

Alkaline phosphatase activity. APA was measured fluorometrically in a Perkin-Elmer fluorometer (PE LS50B) produce the curves in Fig. 1 we used a diffusion rate $D \approx 10^{-5} \mathrm{~cm}^{2} \mathrm{~s}^{-1}\left(3.6 \times 10^{6} \mu \mathrm{m}^{2} \mathrm{~h}^{-1}\right.$ for phosphate in seawater). Analytical solutions to Fick's law for some non-spherical shapes are available (Clift et al. 1978). To visualize the effect of shape, we chose to compare spheres with short rods, where $g=$ length $/ r$ and $0<$ $g \leq 16$. This gives the analytical expressions in Table 1.

Experimental setup. To create a gradient in biomass at steady state, 5 batch cultures forming a gradient in phosphate addition were used for each organism. Sterile $2.0 \mathrm{l}$ Erlenmeyer bottles with $1200 \mathrm{ml}$ of artificial seawater (ASW) medium (Wyman et al. 1985) were amended with phosphate and nitrate in a molar ratio of 80 from sterile aqueous solutions of $\mathrm{NaNO}_{3}$ and $\mathrm{KH}_{2} \mathrm{PO}_{4}$, respectively. For all non-diatoms plus Skeletonema marinoi, a phosphate gradient of $0,0.5,1.0,1.5$ and $2.0 \mu \mathrm{M}$ P (with initially added phosphate) was used, for the other diatoms the gradient was extended: $0.0,1.8,3.6$ and $5.4 \mu \mathrm{M}$ P, and $7.2 \mu \mathrm{M} \mathrm{PO}_{4}$. Trace metal and vitamin solutions were based on the F/2 medium (Guillard 1975). For Heterocapsa triquetra, F/2 medium (Guillard 1975) was used, except for $\mathrm{N}$ and $\mathrm{P}$ which were added as previously explained. The batch cultures were grown on a shaking table at 15 or $20^{\circ} \mathrm{C}$; 3 of 7 cultures were axenic (see Table 1). The bacteria were grown in the dark and the algae in continuous light of $76 \mu \mathrm{mol}$ photons $\mathrm{m}^{-2} \mathrm{~s}^{-1}$.

Cell counts and fluorescence reading were done daily during the experiments to monitor the cell growth and determine when the cultures reached stationary phase. In addition, the following parameters were also measured: particulate $\mathrm{P}(\mathrm{PP})$, soluble reactive $\mathrm{P}$ (SRP), alkaline phosphatase activity (APA), cell abundance and cell size. Bacterial abundance was determined in non-axenic cultures. with methyl-fluorescein-phosphate as substrate (Perry 1972). Values $>1.6 \mathrm{nmol} \mathrm{PO}_{4}{ }^{3-} \mathrm{l}^{-1} \mathrm{~h}^{-1}$ were regarded as positive.

Uptake of orthophosphate $\left({ }^{33} \mathrm{P}\right)$. Uptake kinetics of ${ }^{33} \mathrm{P}$ was measured based on the method of Thingstad et al. (1993). Carrier-free $\mathrm{H}^{33} \mathrm{PO}_{4}$ (Amersham BF 1003) was diluted in Milli-Q water and added to $10 \mathrm{ml}$ samples in $20 \mathrm{ml}$ polyethylene vials to give a final concentration of 3.6 to $6.0 \times 10^{4} \mathrm{~Bq} \mathrm{ml}^{-1}$. Vial contents were mixed after isotope addition and then incubated without shaking. Samples for subtraction of background and abiotic absorption were fixed with $25 \mu \mathrm{l}$ glutaraldehyde before isotope addition. Based on expected turnover time, the length of incubation ranged from 1 to $16 \mathrm{~min}$. Incubation was stopped by a cold chase of $\mathrm{KH}_{2} \mathrm{PO}_{4}$ (final concentration, $1 \mu \mathrm{M}$ ). Aliquots were filtered in parallel on $25 \mathrm{~mm}$ polycarbonate filters with pore sizes according to the type of organism. Bacterial samples were filtered on $0.2 \mu \mathrm{m}$, the axenic culture of Pavlova lutheri on $1.0 \mu \mathrm{m}$, the non-axenic cultures of Tetraselmis suecica, Chaetoceros muelleri and Isochrysis sp. on 0.2 and $2.0 \mu \mathrm{m}$, while diatoms were filtered on 0.2 and $5 \mu \mathrm{m}$ pore size filters. Filtrations were done at low suction $(<0.2 \mathrm{~atm})$ using a 12-place Millipore manifold and Whatman GF/C filters saturated with $100 \mu \mathrm{M} \mathrm{KH}_{2} \mathrm{PO}_{4}$ as support filters. When the entire sample volume had passed the filter, suction was increased to remove medium remaining in the polycarbonate filters. To avoid cell breakage on the filters, no washing step was applied (Thingstad et al. 1993). Filters were then placed in polyethylene scintillation vials with scintillation liquid (Ultima Gold, Packard, Biosciences) and radioassayed in a Liquid Scintillation Analyzer Tri-carb (1900CA). All calculations were made assuming equal quenching in all samples. The turnover time of orthophosphate was calculated as 
$T=-t[\ln (1-\rho)]^{-1}$, where $\rho$ is the fraction of added isotope collected on the $0.2 \mu \mathrm{m}$ filter after incubation time $t$. Radioactivity on the $0.2 \mu \mathrm{m}$ filters, corrected for blank, were assumed to represent total biological uptake.

Size measurements. Size measurements varied according to the type of organism. In order to determine bacterial sizes, samples were put onto 400 mesh Ni-grids with carbon- coated formvar, and left for cells to sink for $10 \mathrm{~min}$. The liquid was then removed by blotting paper. Cell sizes of 8 individual Roseobacter algicola cells were measured from electron micrographs taken at a magnifications from 5000 to $15000 \times$ in a JEOL 100CX transmission electron microscope. A total of 25 cells of Vibrio splendidus were measured directly in a Philips CM 200 electron microscope at a magnification of $10000 \times$.

Algal cell sizes were measured by phase contrast light microscopy. Linear measurements of a minimum of 50 unfixed cells per series were made and converted into the equivalent radius of a spherical cell, except for the Heterocapsa triquetra culture which was fixed in pseudo-Lugol's and for which a total of 10 cells were measured. Volume was calculated using idealized geometrical shapes, and the equivalent spherical diameter calculated.

Abundance of organisms. Diatoms and the dinoflagellate were counted using a haematocytometer (Fuchs Rosenthal) and a light microscope equipped with phase contrast at $100 \times$ magnification. The other flagellates and bacteria were counted by flow cytometry using a FACSCalibur flow cytometer (Becton Dickinson) equipped with an air-cooled laser providing $15 \mathrm{~mW}$ at $488 \mathrm{~nm}$ with the standard filter setup. Enumeration of bacteria was performed on samples fixed with glutaraldehyde for $30 \mathrm{~min}$ at $4^{\circ} \mathrm{C}$. Algae were enumerated from fresh samples. Flow cytometer procedures followed the recommendations of Marie et al. (1999).

Soluble reactive phosphorus measurements. SRP was measured spectrophotometrically using the molybdenum blue reaction described by Koroleff (1976). SRP was measured in triplicate without filtration and corrected for turbidity.

Calculation of affinity. In a batch culture, $\alpha^{\max }$ is expected when external free phosphate as well as internal stores of $\mathrm{P}$ have been depleted, but before senescence occurs. In accordance with this, cultures with different phosphate concentrations reached $\alpha^{\max }$ at different times. Using the $T$ and $B$ pair corresponding to the highest $\alpha$-value for each of the cultures, $\alpha^{\max }$ values and their standard error were calculated from linear regression by fitting the equation $T^{-1}=\alpha^{\max } B$ to these measured $T$ and $B$ pairs, giving up to 5 points for each linear regression. The regressions were forced through the origin. In non-axenic cultures, the term
$T^{-1}$ was exchanged for the term $f T^{-1}$, where $f$ is the fraction of total incorporation going into the size fraction dominated by the organism in question (Thingstad \& Rassoulzadegan 1999).

\section{RESULTS}

All microorganisms grew exponentially to stationary phase. As expected in a medium designed to give a Plimited stationary phase, SRP decreased to low values close to detection limits in all cultures. Both of the 2 bacterial cultures reached the stationary phase within $20 \mathrm{~h}$ and all the algal cultures within $18 \mathrm{~d}$ after the start of the experiment.

Affinity values most closely approaching the theoretical maximum value were anticipated in early stationary phase when external and internal reservoirs of phosphate had been depleted, but before senescence of the P-starved cells. Affinity determinations were therefore initiated based on 3 criteria: (1) reduction in division rate, (2) SRP below or close to detection limit, and (3) induction of alkaline phosphatase. The cultures of bacteria were sampled once for estimation of affinity. Algal cultures were sampled 1 to 6 times as the batch cultures developed and, if different, the $B$ and $f T^{-1}$ values corresponding to the highest $\alpha$ obtained for each culture were used in the regression estimate of $\alpha^{\max }$ (Fig. 1).

The various organisms used in the present study varied in size over more than 1 order of magnitude, from $0.5 \mu \mathrm{m}$ to $7.1 \mu \mathrm{m}$, presented as average equivalent cell radius (Table 2 ).

The highest specific affinity was found for the diatom species Chaetoceros muelleri (0.066 $1 \mathrm{nmol} \mathrm{P}^{-1} \mathrm{~h}^{-1}$ )

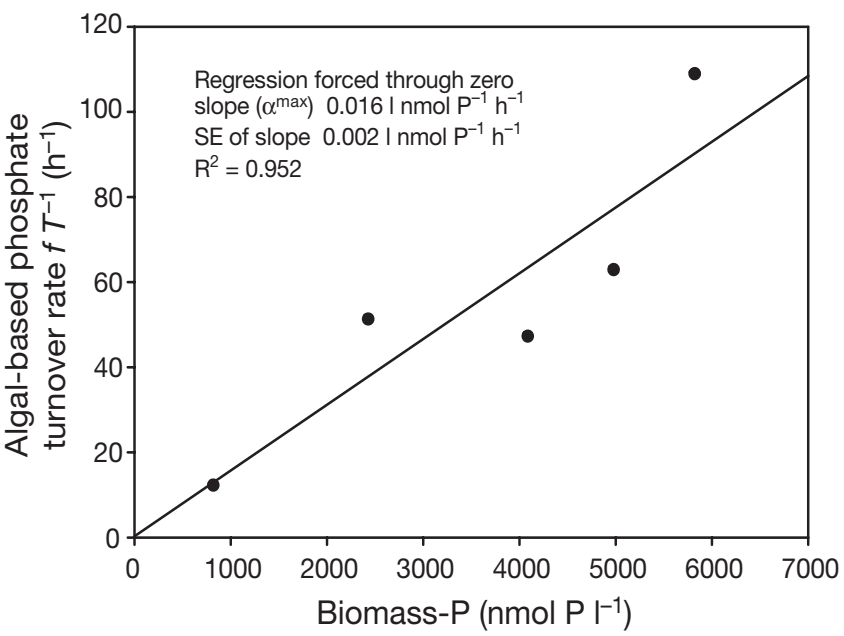

Fig. 1. Thalassiosira weissflogi. Estimation of $\alpha^{\max }$ for the diatom $T$. weissflogi. The $x$-axis is the biomass-P estimated as particulate-P in the appropriate size-fraction; the $y$-axis $\left(f T^{-1}\right)$ is the part $(f)$ of phosphate turnover rate $(1 / T$ where $T$ is phosphate turnover time) ascribed to the appropriate size-fraction 
Table 2. Summary of the organisms used, the measured cell sizes \pm SD and the regression-based (see Fig. 1) estimates of maximum specific affinity $\left(\alpha^{\max } ; \pm\right.$ SE). ESR: equivalent spherical radius

\begin{tabular}{|c|c|c|c|c|c|}
\hline Species & $\begin{array}{l}\text { Axenic } \\
\text { (Yes/no) }\end{array}$ & $\begin{array}{c}\text { Temperature } \\
\left({ }^{\circ} \mathrm{C}\right)\end{array}$ & $\begin{array}{l}\text { ESR } \\
(\mu \mathrm{m})\end{array}$ & $\begin{array}{l}\text { Cultures used for } \\
\text { regression analysis (n) }\end{array}$ & $\begin{array}{c}\alpha^{\max } \\
\left(1 \mathrm{nmol} \mathrm{P^{-1 }} \mathrm{h}^{-1}\right)\end{array}$ \\
\hline \multicolumn{6}{|l|}{ Bacteria } \\
\hline Roseobacter algicola & $\mathrm{Y}$ & 20 & $0.8 \pm 0.4$ & 4 & $0.040 \pm 0.001$ \\
\hline Vibrio splendidus & $\mathrm{Y}$ & 20 & $0.5 \pm 0.1$ & 5 & $0.050 \pm 0.002$ \\
\hline \multicolumn{6}{|l|}{ Diatoms } \\
\hline Chaetoceros muelleri & $\mathrm{N}$ & 15 & $2.2 \pm 0.6$ & 4 & $0.066 \pm 0.008$ \\
\hline Chaetoceros curvisetus & $\mathrm{N}$ & 20 & $6.4 \pm 1.1$ & 3 & $0.026 \pm 0.004$ \\
\hline Thalassiosira weissflogii & $\mathrm{N}$ & 20 & $6.5 \pm 0.7$ & 5 & $0.007 \pm 0.002$ \\
\hline Thalassionema nitzschoides & $\mathrm{N}$ & 20 & $3.7 \pm 0.2$ & 4 & $0.007 \pm 0.002$ \\
\hline Skeletonema marinoi & $\mathrm{N}$ & 20 & $1.9 \pm 0.1$ & 1 & 0.07 \\
\hline Nitzschia longissima & $\mathrm{N}$ & 20 & $1.75 \pm 0.04$ & 5 & $0.028 \pm 0.005$ \\
\hline \multicolumn{6}{|l|}{ Flagellates } \\
\hline Isochrysis sp. & $\mathrm{N}$ & 15 & $1.3 \pm 0.2$ & 5 & $0.0112 \pm 0.0007$ \\
\hline Pavlova lutheri & $\mathrm{Y}$ & 15 & $1.4 \pm 0.2$ & 5 & $0.0147 \pm 0.0008$ \\
\hline Tetraselmis suecica & $\mathrm{N}$ & 15 & $4.1 \pm 0.5$ & 5 & $0.0033 \pm 0.0008$ \\
\hline \multicolumn{6}{|l|}{ Dinoflagellates } \\
\hline Heterocapsa triquetra & $\mathrm{N}$ & 15 & $7.1 \pm 1.5$ & 4 & $0.0020 \pm 0.0003$ \\
\hline
\end{tabular}

(Table 2). The 2 bacterial species had the second and third highest $\alpha$-values $\left(0.04,0.051 \mathrm{nmol} \mathrm{P}^{-1} \mathrm{~h}^{-1}\right)$ while $\alpha$-values for the flagellate were lower by a factor of ca. 3 to 20. The lowest $\alpha$ was measured for the largest organism, the dinoflagellate Heterocapsa triquetra, at $0.0021 \mathrm{nmol} \mathrm{P}^{-1} \mathrm{~h}^{-1}$ (Table 2).

\section{DISCUSSION}

Many aspects related to pelagic food web control are related to particle size, including sedimentation, predation and nutrient competition. Appropriate parameterization of these processes is thus required in order to make realistic numerical models for this ecosystem. The work presented here addresses part of this problem through laboratory experiments intended to provide experimental data suitable for comparison with size-based theoretical models for diffusion-limited uptake of phosphate. We used osmotrophs covering 1 order of magnitude in size, a wide spectrum of taxonomic groups and both heterotrophic and autotrophic modes of energy acquisition.

The general result from Fig. 1 is that experimentally estimated affinities are of the same order of magnitude as the theoretical predictions based on diffusion theory. The predicted decrease in affinity with cell size is reflected in a similar decreasing trend in the observations, covering 2 orders of magnitude in affinity estimates. Likewise, the observation of diatoms having higher affinities than similarly sized flagellates is in accordance with the theory assuming P-free diatom vacuoles. This general agreement between theory and observation supports the basic theoretical assumption that, at sufficiently low external concentrations of phosphate, physical transport by diffusion, rather than any biological process, such as enzymatic uptake, is the rate-limiting process.

When uptake is the rate-limiting process, bacteria have often been speculated to be superior competitors to phytoplankton due to a higher surface:volume ratio. In the models used here, this prediction is modulated by the high P-requirement assumed for bacteria. The bacterial affinities found for Roseobacter algicola and Vibrio splendidus of 0.04 and $0.051 \mathrm{nmol} \mathrm{P}^{-1} \mathrm{~h}^{-1}$, respectively, are slightly below the $\alpha$-values calculated from this theory (Fig. 2). In a recent study, affinities for the same $V$. splendidus isolate was determined for cells grown in P-limited chemostats (Løvdal et al. 2008). Interestingly, this gave higher values (around $0.19 \mathrm{l}$ nmol $\mathrm{P}^{-1} \mathrm{~h}^{-1}$ ), slightly above the theoretical $\alpha^{\max }$ (Fig. 2). It is therefore possible that chemostat conditions, where the cells are allowed to adapt to a stable situation of P-deficiency, may give higher experimental affinity values than batch culture studies where measurements have to be made on cells in a transition phase between growth and senescence. In the lower end of the size spectrum, the largest organism studied, the dinoflagellate Heterocapsa triqueta, also had the lowest affinity estimate $\left(0.002 \mathrm{lnmol} \mathrm{P}^{-1} \mathrm{~h}^{-1}\right)$.

Some of the affinity estimates for diatoms are considerably above the theoretical predictions; for the bacteria and some of the flagellates, values are below the theoretical predictions. Our comparison between experimental and theoretical affinity values contains 3 potential sources of error: (1) errors in the experimental affinity estimates, (2) errors in cell-size determination, or (3) there are features not properly accounted 


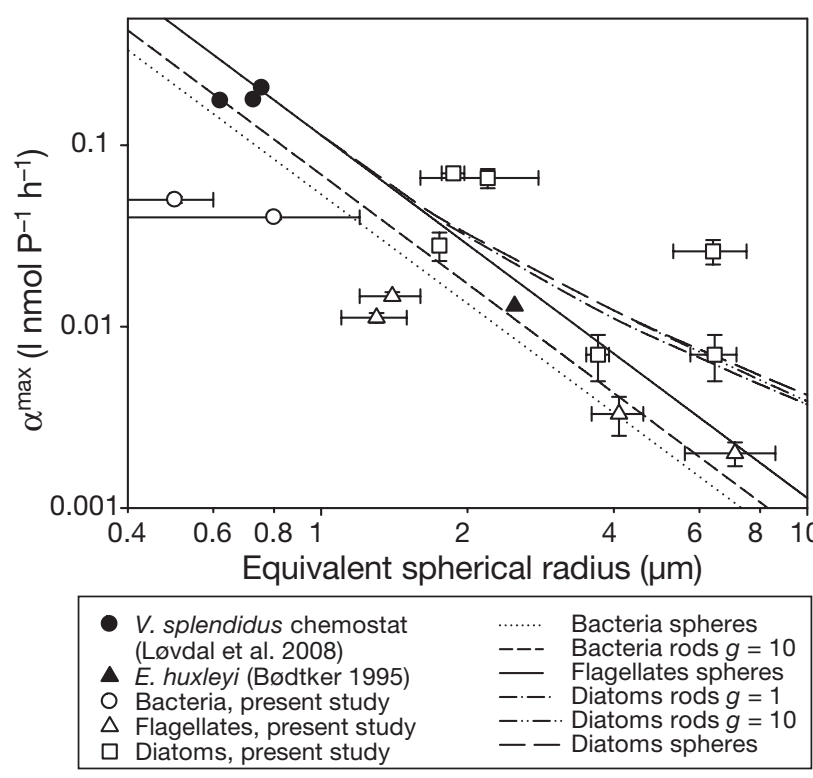

Fig. 2. Theoretical (lines) and experimental affinity estimates (points). The theoretical lines correspond to the models derived in Table 1. Open symbols are results from the present study as summarized in Table 2. Other studies: (•) Vibrio splendidus (bacterium) grown in P-limited chemostats (Løvdal et al. 2008); (ム) Emiliania huxleyi grown in batch cultures (Bødtker 1995). Error bars (when larger than symbol) are as follows: vertical $=\mathrm{SE}$ of estimated slope from regression lines for several cultures with different biomass as explained in 'Materials and methods'; horizontal $=\mathrm{SD}$ of cell equivalent spherical radius. $g$ : cell length/radius

for in the theory. A weakness in our methodology for affinity estimation is that it does not distinguish between $\mathrm{P}$ in live and dead cells. This would bias the results towards underestimation of affinity since 'active' PP would be overestimated. Similarly, phosphate determination using the molybdenium blue method has a potential for interference from silicate (Koroleff 1983), from which one might fear a systematic overestimation of PP in diatoms. As above, however, the result would be an underestimation of affinity and cannot be inferred as an explanation for the high affinity estimates found for some diatoms. Size-determination of microorganisms is not trivial and may be subject to errors from, for example, shrinking during fixation, as was done here for Heterocapsa triqueta. Coefficients of variation in our determination of size are typically of the order of $20 \%$ (Table 2). This is not unexpected in a growing population (for spherical cells doubling in volume before dividing in 2, the theoretical ratio in diameter between newborn and dividing cells is $\sqrt[3]{ } 2 \times 1.26$ ). There are several assumptions affecting the precision of the theoretical model, this includes the calculations for P-content per volume in cytoplasm and the thickness of the cytoplasm layer in diatoms. To a certain extent, our theory accounts for differences in cell shape. As illustrated in Fig. 1, the assumption of a rod shape rather than a spherical shape has very little effect on the theoretical affinity of diatoms. This is because the change in diatom shape is paralleled by a reduction in relative vacuole volume. The predicted difference between rod and spherical shape is thus more pronounced in the case of bacteria (Fig. 2). An interesting alternative morphological feature would be long spines such as the setae possessed by some diatoms. Of the 3 diatoms with affinity estimates above the theoretical prediction, 2 (Chaetocheros muelleri and C. curvisetus) have setae, while the third (Skeletonema marinoi) does not. Since setae can contain polyphosphate bodies (Rogerson et al. 1986), they may also be speculated to be active in phosphate uptake. This likely increases considerably the volume from which the cell can capture phosphate, but for this to work under steady state conditions, an efficient transport mechanism for the acquired phosphate from the site of uptake to the central cell is required. The models used do not take into account the effects of swimming, sinking or turbulence. With organisms well below Kolmogorov scale and incubations for ${ }^{33} \mathrm{P}$ uptake done under still conditions, turbulence is not expected to have influenced the measurements. There is also no visible trend in the data indicating that swimming (flagellates) or sinking (large) organisms have experimental affinity values above the theoretical.

Our affinity estimates are based on a linear regression based on data for cultures with different biomass, the slope of the regression line forced through the origin being used as the estimate of affinity. In several cases, points were omitted from the regression (Table 2) based on the argument that the corresponding cultures either had not reached a state with depletion of both external phosphate and internal P-reservoirs before termination of the experiment, or the culture had clearly reached a state of senescence when affinity measurements were initiated. We checked the cultures for positive APA. It has been debated whether APA is a sign of depletion of external phosphate or of a more severe P-starvation where the internal cell quota approaches minimum and growth is truly P-limited (Van Boekel \& Veldhuis 1990). We only used APA as additional information to measurements of SRP and cell counts, confirming that the cells were in a phase of P-starvation.

We have found a number of studies reporting orthophosphate affinity (Table 3), comprising values for different groups of osmotrophs, and from fresh and marine waters. Precise information on cell sizes and shapes are, however, generally lacking, preventing the inclusion of most of these data in Fig. 1. Our estimates of bacterial affinities around $0.05 \mathrm{lnmol} \mathrm{P}^{-1} \mathrm{~h}^{-1}$ are 
Table 3. Affinity values $(\alpha)$ reported from laboratory and environmental studies. Different methods have been used for calculation: $\alpha=(T B)^{-1}$, the approach used in the present study; $V_{\max } K^{-1}$, standard Michaelis-Menten; $U_{\mathrm{m}} k_{\mathrm{m}}{ }^{-1}$, Michaelis-Menten method based on cellular-P; and $\mathrm{d} V \mathrm{~d} S^{-1}$ which represents the initial slope of the $V S^{-1}$ curve (on the basis of cellular-P)

\begin{tabular}{|c|c|c|c|}
\hline Species & $\begin{array}{l}\text { Method of } \\
\text { calculation }\end{array}$ & $\begin{array}{c}\alpha \\
\left(1 \mathrm{nmol} \mathrm{P}-1 \mathrm{~h}^{-1}\right)\end{array}$ & Source \\
\hline \multicolumn{4}{|l|}{ Bacteria } \\
\hline Strain $3 \mathrm{~h}$ & $U_{\mathrm{m}} k_{\mathrm{m}}^{-1}$ & 0.1 & Vadstein (1998) \\
\hline Strain $2 g$ & $U_{\mathrm{m}} k_{\mathrm{m}}^{-1}$ & 0.02 & Vadstein (1998) \\
\hline Mixed freshwater bacteria community & $U_{\mathrm{m}} k_{\mathrm{m}}{ }^{-1}$ & 0.043 & Vadstein \& Olsen (1989) \\
\hline Strain NV 1.83 & $U_{\mathrm{m}} k_{\mathrm{m}}^{-1}$ & 0.053 & O. Vadstein \& Y. Olsen (unpubl. data) \\
\hline Pseudomonas paucimobilis & $U_{\mathrm{m}} k_{\mathrm{m}}{ }^{-1}$ & 0.15 & Currie \& Kalff (1984) \\
\hline Strain E & $U_{\mathrm{m}} k_{\mathrm{m}}^{-1}$ & 0.075 & Currie \& Kalff (1984) \\
\hline Strain D & $U_{\mathrm{m}} k_{\mathrm{m}}{ }^{-1}$ & 0.030 & Currie \& Kalff (1984) \\
\hline Roseobacter algicola & $\alpha=(T B)^{-1}$ & 0.04 & Present study \\
\hline Vibrio splendidus & $\alpha=(T B)^{-1}$ & 0.05 & Present study \\
\hline Vibrio splendidus & $\alpha=(T B)^{-1}$ & 0.19 & Løvdal et al. (2008) \\
\hline \multicolumn{4}{|l|}{ Cyanobacteria } \\
\hline Anabena flos-aqua & $U_{\mathrm{m}} k_{\mathrm{m}}^{-1 \mathrm{~b}}$ & 0.0060 & Gotham \& Rhee (1981) \\
\hline Oscillatoria agardhii & $U_{\mathrm{m}} k_{\mathrm{m}}^{-1 \mathrm{~b}}$ & 0.004 & Riegman \& Mur(1984) \\
\hline Microcystis sp. & $U_{\mathrm{m}} k_{\mathrm{m}}^{-1 \mathrm{~b}}$ & 0.002 & Gotham \& Rhee (1981) \\
\hline Microcystis aeruginosa & $U_{\mathrm{m}} k_{\mathrm{m}}^{-1}$ & 0.013 & Olsen (1988) \\
\hline Microcystis aeruginosa & $U_{\mathrm{m}} k_{\mathrm{m}}^{-1 \mathrm{~b}}$ & 0.013 & Holm \& Armstrong (1981) \\
\hline \multicolumn{4}{|l|}{ Diatoms } \\
\hline Fragillaria crotonensis & $U_{\mathrm{m}} k_{\mathrm{m}}{ }^{-1 \mathrm{~b}}$ & 0.0009 & Gotham \& Rhee (1981) \\
\hline Cyclotella meneghiniana & $U_{\mathrm{m}} k_{\mathrm{m}}^{-1 \mathrm{~b}}$ & 0.0006 & Tilman \& Kilham (1976) \\
\hline Synedra ulna var. danica & $U_{\mathrm{m}} k_{\mathrm{m}}{ }^{-1}$ & 0.0057 & Currie \& Kalff (1984) \\
\hline Asterionella formosa & $U_{\mathrm{m}} k_{\mathrm{m}}^{-1 \mathrm{~b}}$ & 0.0099 & Gotham \& Rhee (1981) \\
\hline Asterionella formosa & $U_{\mathrm{m}} k_{\mathrm{m}}^{-1 \mathrm{~b}}$ & 0.007 & Holm \& Armstrong (1981) \\
\hline Asterionella formosa & $U_{\mathrm{m}} k_{\mathrm{m}}^{-1 \mathrm{~b}}$ & 0.004 & Tilman \& Kilham (1976) \\
\hline Skeletonema costatum & $V_{\max } K^{-1}$ & 0.017 & Tarutani \& Yamamoto (1994) \\
\hline Chaetoceros muelleri & $\alpha=(T B)^{-1}$ & 0.071 & Present study ${ }^{\mathrm{a}}$ \\
\hline \multicolumn{4}{|l|}{ Flagellates } \\
\hline Chlamydomonas planktogloea & $U_{\mathrm{m}} k_{\mathrm{m}}^{-1}$ & 0.0054 & Currie \& Kalff 1984 \\
\hline Rhodomonas lacustris & $U_{\mathrm{m}} k_{\mathrm{m}}^{-1}$ & 0.017 & Brekke (1987) \\
\hline Rhodomonas sp. & Unknown & 0.010 & R. Riegman et al. (unpubl. data) \\
\hline Phaeocystis globosa pouchetii? & $V_{\max } K^{-1 c}$ & 0.002 & Veldhuis et al. (1991) \\
\hline Nannochloropsis sp. & Unknown & 0.012 & R. Riegman et al. (unpubl. data) \\
\hline Emiliania huxleyi & $\mathrm{d} V \mathrm{~d} S^{-1}$ & 0.020 & Riegman et al. (2000) \\
\hline Emiliania huxleyi & $V_{\max } K^{-1}$ & 0.013 & Bødtker (1995) \\
\hline Isochrysis sp. & $\alpha=(T B)^{-1}$ & 0.016 & Present study \\
\hline Pavlova lutheri & $\alpha=(T B)^{-1}$ & 0.015 & Present study \\
\hline Tetraselmis suecica & $\alpha=(T B)^{-1}$ & 0.009 & Present study \\
\hline \multicolumn{4}{|l|}{ Dinoflagellates } \\
\hline Heterocapsa triquetra & $\alpha=(T B)^{-1}$ & 0.002 & Present study \\
\hline \multicolumn{4}{|l|}{ Other } \\
\hline Ankistrodesmus falcatus & $U_{\mathrm{m}} k_{\mathrm{m}}^{-1 \mathrm{~b}}$ & 0.002 & Gotham \& Rhee (1981) \\
\hline Staurastrum luetkemuellerii & $U_{\mathrm{m}} k_{\mathrm{m}}{ }^{-1}$ & 0.0050 & Olsen (1988) \\
\hline Scenedesmus sp. & $U_{\mathrm{m}} k_{\mathrm{m}}^{-1 \mathrm{~b}}$ & 0.0040 & Gotham \& Rhee (1981) \\
\hline \multicolumn{4}{|l|}{ Environmental samples } \\
\hline $0.2-1.0 \mu \mathrm{m}$, The Sandsfjord, Norway & $V_{\max } K^{-1}$ & 0.023 & Thingstad et al. (1993) \\
\hline$>1 \mu \mathrm{m}$, The Sandsfjord, Norway & $V_{\max } K^{-1}$ & 0.013 & Thingstad et al. (1993) \\
\hline $0.2-0.6 \mu \mathrm{m}$, mixed (eastern Mediterranean) & $\alpha=(T B)^{-1}$ & $0.220^{\mathrm{a}}$ & Moutin et al. (2002) \\
\hline $0.6-2.0 \mu \mathrm{m}$, mixed (eastern Mediterranean) & $\alpha=(T B)^{-1}$ & $0.243^{\mathrm{a}}$ & Moutin et al. (2002) \\
\hline$>2 \mu \mathrm{m}$, mixed (eastern Mediterranean) & $\alpha=(T B)^{-1}$ & $0.026^{\mathrm{a}}$ & Moutin et al. (2002) \\
\hline Bacteria, mixed (Mediterranean) & $\alpha=(T B)^{-1}$ & $0.028^{\mathrm{a}}$ & Tanaka et al. (2003) \\
\hline Cyanobacteria, mixed (Mediterranean) & $\alpha=(T B)^{-1}$ & $0.103^{\mathrm{a}}$ & Tanaka et al. (2003) \\
\hline Autotrophic nanoflagellates, mixed (Mediterranean) & $\alpha=(T B)^{-1}$ & $0.032^{\mathrm{a}}$ & Tanaka et al. (2003) \\
\hline Bacteria, mixed (Mediterranean) & $\alpha=(T B)^{-1}$ & $0.060^{\mathrm{a}}$ & Tanaka et al. (2004) \\
\hline Picophytoplankton, mixed (Mediterranean) & $\alpha=(T B)^{-1}$ & $0.244^{\mathrm{a}}$ & Tanaka et al. (2004) \\
\hline Autotrophic nanoflagellates, mixed (Mediterranean) & $\alpha=(T B)^{-1}$ & $0.127^{\mathrm{a}}$ & Tanaka et al. (2004) \\
\hline$<2.0 \mu \mathrm{m}$, mixed (eastern Mediterranean) & $\alpha=(T B)^{-1}$ & 0.093 & Flaten et al. (2005) \\
\hline \multicolumn{4}{|l|}{${ }^{\mathrm{a}}$ Maximum affinity measured } \\
\hline \multicolumn{4}{|l|}{${ }^{b}$ Recalculated by Vadstein et al. (1989) } \\
\hline${ }^{\mathrm{c} C}$ alculated by Riegman et al. (2000) & & & \\
\hline
\end{tabular}


within the range of values previously reported (0.02 to

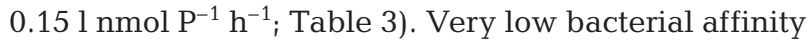
estimates were reported in some early studies (Mitchell 1954, Fuhs et al. 1972, Chen 1974), but have been considered erroneous due to methodological problems (Currie \& Kalff 1984). Except for the dinoflagellate, the experimental affinities for flagellates in the present study vary from 0.002 to $0.015 \mathrm{lnmol}^{-1} \mathrm{~h}^{-1}$. Literature values vary from 0.002 to $0.020 \mathrm{lnmol} \mathrm{P}^{-1}$ $\mathrm{h}^{-1}$, thus covering a very similar range. We are not aware of studies giving affinity values for dinoflagellates, but our low value of $0.0021 \mathrm{nmol} \mathrm{P^{-1 }} \mathrm{h}^{-1}$ fits other claims in the literature of low nutrient competition abilities in dinoflagellates (e.g. Frangopulos et al. 2004).

Some investigations have been performed with bulk natural samples (Table 3), and calculations have been made on the same theoretical basis as the calculations in the present study. For example, Tanaka et al. (2003, 2004) studied the surface waters of the northwestern Mediterranean. Estimated affinities for bacteria, cyanobacteria and autotrophic nanoflagellates ranged from 0.001 to $0.060,0.029$ to 0.244 and 0.001 to 0.1271

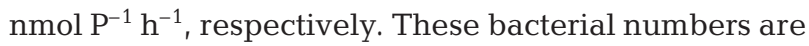
in the same range as our laboratory measurements, while the other 2 size group measurements are slightly higher than our flagellate measurements. Thingstad et al. (1993) found affinities of 0.013 and $0.0231 \mathrm{nmol} \mathrm{P}^{-1}$ $\mathrm{h}^{-1}$ for the size fractions $>1$ and 0.2 to $1.0 \mu \mathrm{m}$, respectively, in the P-limited layer of a Norwegian fjord. These numbers are similar to our numbers for small flagellates and bacteria. With the same technique as used here, Moutin et al. (2002) determined affinities along a W-E transect in the Mediterranean Sea. They found maximum affinities of $0.220 \mathrm{lnmol} \mathrm{P}^{-1} \mathrm{~h}^{-1}$ for the fraction between 0.2 and $0.6 \mu \mathrm{m}, 0.242 \mathrm{lnmol} \mathrm{P}^{-1} \mathrm{~h}^{-1}$ for the fraction between 0.6 and $2.0 \mu \mathrm{m}$ and $0.026 \mathrm{l}$ nmol $\mathrm{P}^{-1} \mathrm{~h}^{-1}$ for the fraction $>2 \mu \mathrm{m}$, i.e. values for the picoplanktonic fractions higher than any value found in our laboratory cultures. In another study from the eastern Mediterranean using the same technique, they found a mean specific affinity of $0.093 \mathrm{nmol} \mathrm{P}^{-1} \mathrm{~h}^{-1}$ for the osmotrophic biomass $<2 \mu \mathrm{m}$ (Flaten et al. 2005). These high values may be another indication that the estimates presented here are conservative, but one can also speculate that permanently P-limited environments like the eastern Mediterranean have organisms physiologically adapted to these conditions and, like the chemostats discussed above, provide a better system for experimental verification of $\alpha^{\text {max }}$-values than the batch cultures used here.

The most important conclusion from the present study is that affinity measurements based on the $\alpha=$ $(T B)^{-1}$ method used here give phosphate affinities comparable to those predicted by a theory assuming diffusion-limited uptake, supporting the validity of this theoretical concept. The general size-dependence and the superiority of the ecologically important diatom group predicted by our simple models are also confirmed. The application of these principles to our understanding and modelling of P-limited systems is therefore supported. While the experimental part of the present study only concerns the uptake of phosphate, the theoretical part is general and, with minor modifications, should be applicable to other limiting substrates such as iron or inorganic $\mathrm{N}$ compounds. The experimental part, however, requires a practically useful radioactive isotope of the element and may be extendable to $\mathrm{Fe}$ using ${ }^{59} \mathrm{Fe}$, but seems difficult to apply to $\mathrm{N}$ where the only radioactive isotope available is ${ }^{13} \mathrm{~N}$ with a half-life of $10 \mathrm{~min}$.

Interestingly, our experimental and theoretical support for particularly high affinities in diatoms may seem difficult to reconcile with previous findings where diatom abundance has been reported to be generally low in P-limited mesocosm experiments (Egge 1998). This may, however, just be a reminder that in natural systems, affinity is only one aspect of in a complex set of positive and negative interactions affecting growth and loss, from which the standing stock of a population is the integrated net result.

Acknowledgements. Å. Hagstrøm, U.-L. Zweifel and H. Havskum are thanked for providing the bacterial and dinoflagellate strains, L. Brunvold and E. F. Skjoldal for skilful assistance with the experiments, M. Heldal for preparation of the electron microscope grids and E. S. Erichsen for assistance at the electron microscope. This study was supported by the University of Bergen and the EU through project NTAP (EVK3-CT-2000-00022).

\section{LITERATURE CITED}

Ammerman J, Hood R, Case D, Cotner J (2003) Phosphorus deficiency in the Atlantic: an emerging paradigm in oceanography. EOS Trans Am Geophys Union 84, doi: 10.1029/2003EO180001

> Björkman K, Thomson-Bulldis AL, Karl DM (2000) Phosphorus dynamics in the North Pacific subtropical gyre. Aquat Microb Ecol 22:185-198

Bødtker G (1995) Is Emiliania huxleyi a good competitor for phosphate? MS thesis, University of Bergen (in Norwegian)

Boyd PW (2002) The role of iron in the biogeochemistry of the Southern Ocean and equatorial Pacific: a comparison of in situ iron enrichments. Deep-Sea Res II 49:1803-1821

> Bratbak G, Dundas I (1984) Bacterial dry-matter content and biomass estimations. Appl Environ Microbiol 48:755-757

Brekke O (1987) Phosphorus limited growth and phosphate uptake of freshwater algae: chemostat studies of Rhodomonas lacustris (Cryptophyceae) and competition studies in a eutrophic lake. MS thesis, University of Trondheim (in Norwegian)

> Chen M (1974) Kinetics of phosphorus absorption by Corynebacterium bovis. Microb Ecol 1:164-175

Clift R, Grace JR, Weber ME (1978) Bubbles, drops, and particles. Academic Press, New York 
Currie DJ, Kalff J (1984) A comparison of the abilities of freshwater algae and bacteria to acquire and retain phosphorus. Limnol Oceanogr 29:298-310

Droop MR (1967) A procedure for routine purification of algal cultures with antibiotics. Br Phycol Bull 3:295-297

Egge JK (1998) Are diatoms poor competitors at low phosphate concentrations? J Mar Syst 16:191-198

Flaten GAF, Skjoldal EF, Krom MD, Law CS and others (2005) Studies of the microbial P-cycle during a Lagrangian phosphate-addition experiment in the Eastern Mediterranean. Deep-Sea Res II 52:2928-2943

Frangopulos M, Guisande C, deBlas E, Maneiro I (2004) Toxin production and competitive abilities under phosphorus limitation of Alexandrium species. Harmful Algae 3: 131-139

Fuhs GW, Demmerle DS, Cannelli E, Chen M (1972) Characterization of phosphorus-limited plankton algae (with reflections on the limiting-nutrient concept). Limnol Oceanogr Spec Symp 1:113-133

> Gasol JM, Pedros-Alio C, Vaque D (2002) Regulation of bacterial assemblages in oligotrophic plankton systems: results from experimental and empirical approaches. Antonie Leeuwenhoek 81:435-452

Gotham IJ, Rhee GY (1981) Comparative kinetic studies of phosphate-limited growth and phosphate uptake in phytoplankton in continuous culture. J Phycol 17: 257-265

Guillard RRL (1975) Culture of phytoplankton for feeding marine invertebrates. In: Smith WL, Chanley MH (eds) Culture of marine invertebrate animals. Plenum Press, New York, p 29-60

> Hagström A, Pinhassi J, Zweifel UL (2000) Biogeographical diversity among marine bacterioplankton. Aquat Microb Ecol 21:231-244

Holm NP, Armstrong DE (1981) Role of nutrient limitation and competition in controlling the populations of Asterionella formosa and Microcystis aeruginosa in semicontinuous culture. Limnol Oceanogr 26:622-634

> Hudson JJ, Taylor WD, Schindler DW (2000) Phosphate concentrations in lakes. Nature 406:54-56

> Isvánovics V, Shafik HM, Présing M, Juhos S (2000) Growth and phosphate uptake kinetics of the cyanobacterium, Cylindrospermopsis raciborskii (Cyanophyceae) in throughflow cultures. Freshw Biol 43:257-275

Jumars P, Deming J, Hill P, Karp-Boss L, Dade W (1993) Physical constraints on marine osmotrophy in an optimal foraging context. Mar Microb Food Webs 7:121-161

Karl DM, Bjorkman KM, Dore JE, Fujieki L and others (2001) Ecological nitrogen-to-phosphorus stoichiometry at station ALOHA. Deep-Sea Res II 48:1529-1566

Kiørboe T (2008) A mechanistic approach to plankton ecology. Princeton University Press, Princeton, NJ

Koroleff F (1976) Determination of phosphorous. In: Grasshoff $\mathrm{K}$ (ed) Methods of seawater analysis. Verlag Chemie, Weinheim, p 125-131

Koroleff F (1983) Determination of total phosphorus by acid persulphate oxidation. In: Grasshoff $\mathrm{K}$, Erhardt M, Kremling $\mathrm{K}$ (eds) Methods of seawater analysis. Verlag Chemie, Weinheim, p 134-136

Løvdal T, Skjoldal EF, Heldal M, Norland S, Thingstad TF (2008) Changes in morphology and elemental composition of Vibrio splendidus along a gradient from carbon-limited to phosphate-limited growth. Microb Ecol 55:152-161

Marie D, Partensky F, Vaulot D, Brussaard CPD (1999) Enumeration of phytoplankton, bacteria, and viruses in marine samples. In: Current protocols in cytometry. John Wiley \& Sons, Somerset, NJ, p 11.11.11-11.11.15
Mitchell P (1954) Transport of phosphate across the osmotic barrier of Micrococcus pyogenes: specificity and kinetics. J Gen Microbiol 11:73-82

Moutin T, Thingstad T, Van Wambeke F, Marie D, Slawyk G, Raimbault O, Claustre H (2002) Does competition for nanomolar phosphate supply explain the predominance of the cyanobacterium Synechococcus? Limnol Oceanogr 47:1562-1567

Olsen Y (1988) Phosphate kinetics and competitive ability of planktonic blooming cyanobacteria under variable phosphate supply. PhD dissertation, University of Trondheim, Norway

Perry MJ (1972) Alkaline phosphatase activity in subtropical Central North Pacific waters using a sensitive fluorometric method. Mar Biol 15:113-119

> Riegman R, Mur LR (1984) Regulation of phosphate-uptake kinetics in Oscillatoria agardhii. Arch Microbiol 139: $28-32$

Riegman R, Stolte W, Noordeloos A, Slezak D (2000) Nutrient uptake, and alkaline phosphate (EC 3:1:3:1) activity of Emiliania huxleyi (Prymnesiophyceae) during growth under $\mathrm{N}$ and $\mathrm{P}$ limitation in continuous cultures. J Phycol 36:87-96

Rogerson A, Defreitas ASW, McInnes AG (1986) Growth-rates and ultrastructure of siliceous setae of Chaetoceros gracilis (Bacillariophyceae). J Phycol 22:56-62

> Schmidt L, Hansen P (2001) Allelopathy in the prymnesiophyte Chrysochromulina polylepis: effect of cell concentration, growth phase and $\mathrm{pH}$. Mar Ecol Prog Ser 216: 67-81

Tanaka T, Rassoulzadegan F, Thingstad TF (2003) Measurements of phosphate affinity constants and phosphorus release rates from the microbial food web in Villefranche Bay, northwestern Mediterranean. Limnol Oceanogr 48:1150-1160

Tanaka T, Rassoulzadegan F, Thingstad TF (2004) Orthophosphate uptake by heterotrophic bacteria, cyanobacteria, and autotrophic nanoflagellates in Villefranche Bay, northwestern Mediterranean: vertical, seasonal, and short-term variations of the competitive relationship for phosphorus. Limnol Oceanogr 49:1063-1072

Tarutani K, Yamamoto T (1994) Phosphate uptake and growth kinetics of Skeletonema costatum isolated from Hiroshima Bay. J Fac Appl Biol Sci Hiroshima Univ 33:65-80

Thingstad T (2000) Control of bacterial growth in idealised food webs. In: Kirchman DL (ed) Microbial ecology of the ocean. John Wiley \& Sons, New York, p 229-259

Thingstad T, Rassoulzadegan F (1999) Conceptual models for the biogeochemical role of the photic zone food web, with particular reference to the Mediterranean Sea. Prog Oceanogr 44:271-286

> Thingstad TF, Skjoldal EF, Bohne RA (1993) Phosphorus cycling and algal-bacterial competition in Sandsfjord, western Norway. Mar Ecol Prog Ser 99:239-259

Thingstad TF, Zweifel UL, Rassoulzadegan F (1998) P limitation of heterotrophic bacteria and phytoplankton in the northwest Mediterranean. Limnol Oceanogr 43:88-94

Thingstad TF, Havskum H, Zweifel UL, Berdalet E and others (2007) Ability of a 'minimum' microbial food web model to reproduce response patterns observed in mesocosms manipulated with $\mathrm{N}$ and $\mathrm{P}$, glucose, and Si. J Mar Syst 64:15-34

Tilman D, Kilham SS (1976) Phosphate and silicate growth and uptake of the diatoms Asterionella formosa and Cyclotella meneghiniana in batch and semicontinuous culture. J Phycol 12:375-383

Vadstein O (1998) Evaluation of competitive ability of two 
heterotrophic planktonic bacteria under phosphorus limitation. Aquat Microb Ecol 14:119-127

Vadstein O, Olsen Y (1989) Chemical composition and phosphate uptake kinetics of limnetic bacterial communities cultured in chemostats under phosphorus limitation. Limnol Oceanogr 34:939-946

van Boekel WHM, Veldhuis MJW (1990) Regulation of alkaline phosphatase synthesis in Phaeocystis sp. Mar Ecol Prog Ser 61:281-289

Veldhuis MJW, Colijn F, Admiraal W (1991) Phosphate utilization in Phaeocystis pouchetii (Haptophyceae). Mar Ecol 12:53-62

Vidal M, Duarte CM, Agustí S, Gasol JM, Vaqué D (2003)

Submitted: May 4, 2009; Accepted: August 31, 2009
Alkaline phosphatase activities in the central Atlantic Ocean indicate large areas with phosphorus deficiency. Mar Ecol Prog Ser 262:43-53

Wilhelm S, Suttle C (1999) Viruses and nutrient cycles in the sea. BioScience 49:781-788

Wu J, Sunda W, Boyle EA, Karl DM (2000) Phosphate depletion in the western North Atlantic Ocean. Science 289:759-762

Wyman M, Gregory RPF, Carr NG (1985) Novel role for phycoerythrin in a marine cyanobacterium, Synechococcus strain DC2. Science 230:818-820

Zohary T, Robarts RD (1998) Experimental study of microbial $\mathrm{P}$ limitation in the eastern Mediterranean. Limnol Oceanogr 43:387-395

Proofs received from author(s): October 1, 2009 